\title{
A Ação Libertadora Nacional, a revolução cubana e a luta armada no Brasil
}

\author{
Jean Rodrigues Sales ${ }^{* *}$
}

O objetivo do artigo é analisar as relações da Ação Libertadora Nacional com a revolução cubana na década de 1960. Parte do pressuposto de que a revolução cubana representou um marco na história do socialismo no continente latino-americano. Uma das marcas distintivas dessa história foi a profunda influência que teve sobre as organizações que participaram da luta armada contra a ditadura brasileira implantada em 1964. Nesse caminho, discutiremos aqui o tipo de influência que a revolução cubana teve sobre a ALN, principalmente no que diz respeito ao seu projeto de luta armada.

Palavras-chave: Ação Libertadora Nacional - Revolução cubana - Luta armada

National Liberation Action, the cuban revolution and armed struggle in Brazil The present article analyzes the relationship between the National Liberation Action party and the Cuban revolution in the 1960's. It is based on the assumption that

\footnotetext{
*Artigo recebido em novembro de 2007 e aprovado para publicação em maio de 2008.

** Doutor em História Social pela UNICAMP. Pós-doutorando no Departamento de História da FFLCH-USP. Bolsista da FAPESP. E-mail: jeanrodrigues5@yahoo.com.br. Eu retomo, neste artigo, discussões que realizei em $O$ impacto da revolução cubana sobre as organizações comunistas brasileiras (1959-1974), tese de doutorado (História), Campinas, IFCH-UNICAMP, 2005, e em um livro recentemente publicado (A luta armada contra a ditadura militar. A esquerda brasileira e a influência da revolução cubana, São Paulo, Perseu Abramo, 2007).
} 
the Cuban Revolution represented a landmark in the history of socialism in Latin America. One of the Revolution's outstanding features was its influence on the organizations that took part in armed combat against the Brazilian dictatorship which was established in 1964. It is with this perspective in mind that we intend to discuss the influence the Cuban revolution had on the ALN, especially with regards to its project for establishing armed revolutionary struggle in Brazil.

Keywords: National Liberation Action - Cuban Rvolution - Armed Struggle

\section{L'Action Libératrice Nationale, la révolution cubaine et la lutte armée au Brésil}

Le but de cet article est d'analyser les rapports qu'entretenait l'Action Libératrice Nationale avec la révolution cubaine aux années 60 en s'appuyant sur la prémisse que la révolution cubaine est un repère historique du socialisme en Amérique Latine. Son influence profonde sur les organisations qui ont participé à la lutte armée contre la dictature brésilienne établie en 1964 est considérée une marque distinctive de cette histoire. C'est à partir de ce point de vue que nous discuterons ici le type d'influence que la révolution cubaine a eu sur l'ALN, notamment par rapport à son projet de lutte armée.

Mots-clés: Action Libératrice Nationale - Révolution Cubaine - Lutte Armée

\section{Introdução}

O senhor é maoísta? Sou brasileiro. Sou o que a prática revolucionária exercida no contexto brasileiro fez de mim. Seguimos nosso próprio caminho e se chegamos a pontos de vista semelhantes aos de Mao, Ho Chi Minh, Fidel Castro, Guevara etc., não terá sido de propósito (...). Mas, se se pode falar de inspiração, a nossa vem, sobretudo, de Cuba e do Vietnam. A experiência cubana, para mim, foi determinante, sobretudo no que se refere à organização de um pequeno grupo inicial de combatentes. ${ }^{1}$

O diálogo acima faz parte da última entrevista concedida por Carlos Marighella, principal líder e teórico da Ação Libertadora Nacional (ALN), ${ }^{2}$

1 "O Brasil será um novo Vietnã" [trecho de entrevista de Carlos Marighella ao semanário francês Front, em novembro de 1969], in: Edgard Carone, O movimento operário no Brasil (1964-1984), São Paulo, DIFEL, 1984, p. 63-70.

${ }^{2}$ Sobre a história da ALN e de Carlos Marighella, ver: Marcelo Ridenti, O fantasma da revolução brasileira, São Paulo, Editora da UNESP, 1993; Jacob Gorender, Combate nas trevas, 6. ed. rev, São Paulo, Ática, 1998 e Cristiane Nova e Jorge Nóvoa (orgs.), Carlos Marighella: $o$ homem por trás do mito, São Paulo, Editora da UNESP, 1999. 
a um semanário francês. A resposta do revolucionário brasileiro serve para adiantar a forma como pretendo analisar, neste artigo, a influência da revolução cubana sobre a ALN. Em primeiro lugar, não se trata de buscar ligações esquemáticas entre as ideias cubanas e o surgimento e a atuação do agrupamento brasileiro, que em vários documentos, inclusive na epígrafe acima, rejeita tal interpretação. ${ }^{3}$

Ao mesmo tempo, porém, trata-se de buscar o entendimento de como e em que medida a teoria revolucionária que emanou da ilha de Fidel Castro marcou e influenciou a trajetória da ALN, o que também, assim acredito, está claramente exposto no programa revolucionário da organização. A propósito dessa influência, certamente deve-se a ela o fato de alguns autores defenderem que a ALN "foi a principal representante da linha castro-guevarista no Brasil", ${ }_{4}$ ou que Marighella "foi a personificação brasileira de uma estratégia de ação continental concebida sob influência direta da revolução cubana: a guerra de guerrilhas latino-americana". ${ }^{5}$

\section{Ogolpe de 1964, a crise do PCB e a insurgência de Carlos Marighella}

As divergências de Carlos Marighella com a direção do Partido Comunista Brasileiro (PCB) remontam pelo menos a 1961, no momento da renúncia de Jânio Quadros, as quais, porém, só se tornaram públicas com a crise que

\footnotetext{
${ }^{3}$ Para uma crítica à vertente que tenta explicar a história da esquerda brasileira a partir de suas relações internacionais, ver Daniel Aarão Reis Filho, A revolução faltou ao encontro, 2. ed., São Paulo, Brasiliense, 1990 e Jean Rodrigues Sales, O impacto da revolução cubana sobre as organizações comunistas brasileiras (1959-1974), op. cit.

${ }^{4}$ Carlos Alberto Barão, "A influência da revolução cubana sobre a esquerda brasileira nos anos 60", in: João Quartim de Moraes e Daniel Aarão Reis Filho (orgs.), História do marxismo no Brasil, 2. ed. rev, Campinas, Ed. da UNICAMP, 2003, p. 291. Para os objetivos deste artigo e amparado nos documentos das organizações comunistas do período, uso como sinônimos termos como foquismo, guevarismo, castro-guevarismo e debraysmo. Emprego as expressões aqui de forma ampla, como eram utilizadas entre as esquerdas nos anos 1960, caracterizando, de uma forma geral, movimentos que, influenciados pela revolução cubana, acreditavam ser possível fazer uma revolução socialista através da guerra de guerrilhas e sem a presença de um partido comunista. Acreditava-se que esse era um caminho adequado para a América Latina e que as condições objetivas estavam prontas, restando criar as condições subjetivas, tarefa esta que a presença do foco guerrilheiro se encarregaria. Uma vez iniciados os combates, as massas acabariam por se aliar aos guerrilheiros, e estes conseguiriam aumentar a sua força até a tomada do poder. Durante o processo revolucionário, a guerrilha seria a vanguarda política, estando todas as outras tarefas a ela subordinadas.

${ }^{5}$ Muniz Ferreira, "Carlos Marighella: revolução e antinomias”, in: Cristiane Nova e Jorge Nóvoa (orgs.), op. cit., p. 221.
} 
tomou conta do partido após o golpe de $1964^{6}$ e com a crescente oposição que Marighella e outros dirigentes passaram a adotar em face da direção partidária. A insatisfação veio a público com a elaboração, em maio de 1964, do primeiro pronunciamento partidário após o golpe, intitulado de Esquema para discussão. O documento refletia o ponto de vista de Mário Alves, Jover Telles, Jacob Gorender, Giocondo Dias, Orlando Bonfim e Marighella. ${ }^{7}$ Entre outras coisas, o Esquema para discussão afirmava que a causa da derrota diante dos golpistas estava no fato de o PCB ter incorrido em grave "desvio de direita", na medida em que alimentara ilusões a respeito do alcance das reformas de base por meio pacífico, acreditando na aliança com a burguesia nacional e "conciliando objetivamente com um governo burguês", não tendo, assim, preparado as massas para resistir ao golpe. ${ }^{8}$

Em maio de 1965, ocorreu a primeira reunião do Comitê Central após a chegada dos militares ao poder. Nela, diferentemente do que afirmava o Esquema para discussão, prevaleceu a ideia de que o problema residira em um "desvio de esquerda" que o partido havia adotado, na medida em que haveria abandonado a bandeira da legalidade nas mãos dos inimigos e superestimado o nível de enraizamento e coesão das forças democráticas. ${ }^{9}$ Em suma, a linha política que havia sido traçada no $\mathrm{V}$ Congresso deveria ser salva, pois apenas havia sido mal aplicada na conjuntura que antecedeu o golpe. Durante o encontro, segundo Jacob Gorender, Marighella teria evitado confronto com a maioria dos presentes, uma vez que pretendia manter o seu posto na Comissão Executiva, o que de fato conseguiu. ${ }^{10}$

No segundo semestre de 1965, foi publicado o livro Porque resisti à prisão, escrito por Carlos Marighella, no qual ele relata o episódio de sua prisão em um cinema no Rio de Janeiro, para, em seguida, ainda que de forma incipiente, fazer uma análise da ditadura militar e das causas da derrota do campo democrático. É neste livro que Marighella começa a elaborar suas ideias a respeito da luta contra o regime militar, inclusive no que diz respeito à luta

\footnotetext{
${ }^{6}$ Cristiane Nova e Jorge Nóvoa, "Genealogias, transversalidades e rupturas de Carlos Marighella”, in: Cristiane Nova e Jorge Nóvoa (orgs.), op. cit., p. 87-89.

${ }^{7}$ Jacob Gorender, op. cit., p. 95. Já na versão de Moisés Vinhas, o documento sintetizava as ideias de Mário Alves, Marighella, Gorender, Telles e Apolônio de Carvalho (Moisés Vinhas, O partidão. A luta por um partido de massas (1922-1974), São Paulo, HUCITEC, 1982, p. 237).

${ }^{8}$ Moisés Vinhas, op. cit., p. 236.

${ }^{9}$ Ibidem, p. 237.

${ }^{10}$ Jacob Gorender, op. cit., p. 97.
} 
armada, que estarão presentes no momento da criação da ALN. Entretanto essas primeiras formulações do futuro guerrilheiro estão distantes daquelas que colocarão ação e guerrilha como marca central de sua atuação política.

A maior parte de Porque resisti à prisão, ${ }^{11}$ dezesseis dos dezoito capítulos, relata a prisão, o ferimento que sofreu, a passagem pelo hospital, a tortura e o processo que respondeu enquanto estava sob poder da polícia. Nos dois últimos capítulos, ${ }^{12}$ Marighella faz uma análise das possibilidades de luta contra a ditadura. O que chama atenção é que as propostas apresentadas são pouco radicais se comparadas com as formulações que a ALN adotará três anos depois. A ênfase das proposições recai sobre a necessidade de uma luta que seja feita junto com as massas, para fugir do isolamento que o PCB teria experimentado antes do golpe. A "frente única antiditadura" não poderia ser liderada pela burguesia, cujos interesses estavam atrelados aos dos militares. O conteúdo da luta seria: "de oposição popular e de combate cerrado à ditadura. E somente com este conteúdo, a luta das forças populares e democráticas terá êxito". A questão central que estava envolvida era "o problema das liberdades democráticas". ${ }^{13}$

Sobre os caminhos da luta política, Marighella não assume a via armada como o único modo possível de oposição à ditadura. Para ele, "a solução do problema brasileiro por uma via pacífica se distanciou enormemente da realidade". Ainda assim, insiste que "se trata de realizar uma luta revolucionária de massa, extensa e profunda". ${ }^{14}$ De qualquer forma, o líder revolucionário entrevê a possibilidade de outras formas de atuação, inclusive o "aparecimento de guerrilhas". ${ }^{15}$

Por fim, a revolução cubana já aparece como "exemplo ilustrativo" de como muitos países latino-americanos poderiam conseguir sua independência política e progresso social. Para Marighella, naquele momento, não se tratava de tentar copiar as situações vivenciadas em Cuba, mas sim apreender as lições

\footnotetext{
${ }^{11}$ Carlos Marighella, Porque resisti à prisão, São Paulo, Brasiliense; Salvador, EDUFBA, Olodum, 1995.

${ }^{12}$ Jacob Gorender sugere que os dois últimos capítulos foram escritos após a reunião do C. C. de maio de 1965, quando o documento apoiado de Marighella foi derrotado, o que explicaria o teor mais radical do final do livro (Jacob Gorender, op. cit., p. 103).

${ }^{13}$ Carlos Marighella, Porque resisti à prisão, op. cit., p. 103-104.

${ }^{14}$ Ibidem, p. 141-142.

${ }^{15}$ Ibidem, p. 141.
} 
e apreciar a validade das teses táticas e princípios revolucionários postos em ação naquele país. ${ }^{16}$

A intervenção seguinte de Marighella no debate interno do PCB, que se deu com a publicação, ainda em 1966, de um texto intitulado A crise brasileira, aprofundou as questões que ele havia apenas esboçado em Porque resisti à prisão, principalmente no que diz respeito à atuação política do partido e à tentativa de definir uma estratégia de luta armada para o Brasil. Em relação ao PCB, afirmaria que, já na crise da renúncia de Jânio Quadros, havia ficado claro que o partido estava despreparado para enfrentar a situação, o que veio a se confirmar na queda de João Goulart. A origem do problema estaria em uma política de dependência em face da burguesia e do governo, ao mesmo tempo em que mantinha um trabalho apenas de cúpula junto ao proletariado e não dava qualquer atenção à organização dos camponeses. ${ }^{17}$ A nova situação não podia ser resolvida segundo a fórmula anterior ("caminho pacífico e apoio à burguesia na luta pelas reformas”). Nesse sentido, Marighella se esforçaria em traçar uma nova forma de atuação política, cuja característica central será a tentativa de união entre luta de massas e luta armada. Em suas palavras:

(...) os fatos indicam que o proletariado - em face do tremendo impacto da abrilada - não tem outro recurso senão adotar uma estratégia revolucionária que leve à derrubada da ditadura. Trata-se da revolução, da preparação da "insurreição armada popular". Trata-se do caminho não pacífico, violento, até mesmo da guerra civil. Sem o recurso à violência por parte das massas, a ditadura será institucionalizada por um período de maior ou menor duração. ${ }^{18}$

Esse caminho, chamado pelo revolucionário de "não pacífico", de "violento", aparece, na prática, como uma proposta de luta guerrilheira que vem, entretanto, acompanhada de uma série de ressalvas, o que a distancia ainda das propostas da ALN. Em primeiro lugar, a guerrilha é apontada como "uma das formas da luta de resistência das massas" e como "uma forma de luta complementar", "que em si mesma não decide a vitória final". ${ }^{19}$ Uma segunda característica é que ela "não é inerente às cidades, não é uma forma

\footnotetext{
${ }^{16}$ Ibidem, p. 142.

17 “A crise brasileira”, in: Carlos Marighella, Escritos de Carlos Marighella, São Paulo, Editorial Livramento, 1979, p. 49.

${ }^{18}$ Ibidem, p. 61.

${ }^{19}$ Ibidem, p. 84.
} 
de luta apropriada às áreas urbanas", ${ }^{20} \mathrm{e}$, mais do que isso, ela é pensada como resultado de um profundo enraizamento junto ao campesinato.

Ainda nesse caminho, o futuro líder da ALN pensava a guerrilha como parte integrante de um amplo movimento de massas contra a ditadura militar, fora da qual seria um tipo de luta praticamente inviável: "nada parece aprovar a ideia de uma luta guerrilheira que não surja das entranhas do movimento camponês e do movimento de massas, da resistência do povo brasileiro". ${ }^{21}$ Por fim, o último parágrafo de $A$ crise brasileira apresenta uma ideia que se distancia enormemente daquelas dos defensores do foquismo como estratégia política para a revolução na América Latina. Para Marighella, a guerrilha não seria a responsável pelo desencadeamento da luta contra a ditadura, mas sim pensada como mais um elemento da frente ampla de luta contra o regime militar:

(...) ninguém espera que a guerrilha seja o sinal para o levante popular ou para a súbita proliferação de focos insurrecionais. Nada disso. A guerrilha será o estímulo para o prosseguimento da luta de resistência por toda parte. Para o aprofundamento da luta pela formação da frente-única antiditadura. Para o esforço final da luta de conjunto, de todos os brasileiros, luta que acabará pondo por terra a ditadura. ${ }^{22}$

É importante lembrar que essas propostas a respeito da guerrilha estão inseridas no debate interno do $\mathrm{PCB}$, resultando na saída de grande parte dos militantes fundadores das organizações guerrilheiras. Nesse debate, um dos polos aglutinadores era representado exatamente pelo Comitê Estadual de São Paulo, que tinha como principal liderança Carlos Marighella. Assim, em meados de 1966, Marighella foi eleito primeiro secretário do comitê paulista, em clara afirmação de inconformismo diante do C. C., já tornado público após a publicação de Porque resisti à prisão. Em dezembro, firmando mais um passo na luta interna, ele se demite da Comissão Executiva, não sem enfatizar que esta, além de inerte, subordinava "a tática do proletariado à burguesia" e que a saída para o Brasil só poderia se dar através da "luta armada, do caminho revolucionário, da preparação da insurreição armada do povo, com todas as consequências e implicações que daí resultam". ${ }^{23}$

\footnotetext{
${ }^{20}$ Ibidem, p. 85.

${ }^{21}$ Ibidem, p. 87.

${ }^{22}$ Ibidem, p. 88.

23 “Carta à executiva”, in: Escritos de Carlos Marighella, op. cit., p. 91-93.
} 
Entre abril e junho de 1967, aconteceriam os últimos lances da participação de Carlos Marighella no debate interno do PCB. Em abril, em Conferência realizada na cidade de Campinas, com a presença de uma delegação chefiada por Luis Carlos Prestes, 33 dos 37 delegados presentes rejeitaram as teses do C. C. e aprovaram o informe apresentado por Marighella, que foi reeleito primeiro secretário do C. E. de São Paulo. ${ }^{24}$ Em junho, ele ainda se pronunciou a respeito das teses apresentadas para o VI Congresso do PCB, que se realizaria no final do ano. Mais uma vez, o primeiro secretário de São Paulo criticou a subordinação do partido à burguesia e o fato de as teses não optarem claramente pelo caminho pacífico ou pela via armada. ${ }^{25}$ Por fim, contrastando com a proposta do C. C., que se apoiava na proposição de uma ampla frente política pelas liberdades democráticas, afirmava que o objetivo dos revolucionários deveria ser de maior alcance: "substituir tal governo ditatorial por um governo que assegure a independência do país. E isto não será possível pela via pacífica, mas sim pela via armada e com a unidade das forças populares". 26

Entre 31 de julho e 10 de agosto de 1967, aconteceu em Cuba a Conferência da Organização Latino-Americana de Solidariedade (OLAS), que significou, em certa medida, uma tentativa por parte dos cubanos de tornarem-se um centro revolucionário no continente. Entre outras formulações, a OLAS criticou a política defendida pelos partidos comunistas e indicou a luta guerrilheira como estratégia adequada para a maior parte dos países latino-americanos, proclamando que o dever de todo revolucionário era o de "fazer a revolução". ${ }^{27}$ Por estes e outros motivos, o PCB negou-se a participar da Conferência, além de lhe ter feito críticas publicamente. Entretanto, para surpresa de seus dirigentes, souberam não somente da presença de Carlos Marighella na reunião, mas ainda que este tinha criticado a política adotada pelo partido no Brasil. Diante dessa situação, o C. C. o expulsou do partido.

\section{Aguerrilha como único caminho para a revolução brasileira}

\footnotetext{
${ }^{24}$ Sobre a crise interna no PCB, ver Jacob Gorender, op. cit., p. 95-101.

25 "Críticas às teses do Comitê Central", in: Escritos de Carlos Marighella, op. cit., p. 103-109. Marighella ainda insistiria nas críticas às teses do C. C., no texto "Ecletismo e Marxismo", publicado em 1967, in: ibidem, p. 113-116.

${ }^{26}$ Ibidem, p. 110.

${ }^{27}$ A Declaração da OLAS pode ser vista in: Michael Löwy, O marxismo na América Latina. Uma ontologia de 1909 aos dias atuais, São Paulo, Fundação Perseu Abramo, 1999, p. 303-314.
} 
A viagem de Carlos Marighella a Cuba, entre junho e dezembro de 1967, desempenhou um papel importante em sua trajetória pessoal e em suas formulações teóricas. Nas palavras de Jacob Gorender, seu pensamento sofreu uma flexão, "para a qual já estava propenso e que, sem dúvida, não se verificaria tão depressa sem o influxo direto das teses cubanas". ${ }^{28}$ A primeira e principal mudança ocorrida nas elaborações de Marighella é que a guerrilha passa a ser vista como a única forma de luta contra a ditadura e como desencadeadora da consciência revolucionária no país, aspecto este característico das formulações foquistas. Tais mudanças no pensamento de Carlos Marighella aparecerão já em seu primeiro documento escrito em Cuba, Carta ao Comitê Central, no qual responde às críticas que havia sofrido da direção do PCB. Em suas palavras:

(...) a luta guerrilheira é a única maneira de reunir os revolucionários brasileiros e de levar nosso povo à conquista do poder. Recursos humanos e condições para a guerrilha não faltam no Brasil. A consciência revolucionária, que brota na luta, se incumbirá do resto. A guerrilha é o que pode haver de mais anticonvencional e de mais antiburocrático, o que mais se distancia do sistema tradicional de um partido da cidade. ${ }^{29}$

Ainda em Cuba, Marighella continuaria a dar mostras de sua aproximação das ideias foquistas, sobretudo do pressuposto de que seria possível, após a eclosão da luta guerrilheira, expandir as forças revolucionárias até chegar ao poder. Nesse sentido, de forma bastante otimista, afirmava que havia condições para a luta armada no Brasil, uma vez que vigorava no país um contexto semelhante ao que existia em Cuba antes da revolução: o controle do imperialismo norte-americano na produção, no poder político e militar, os problemas do campo e a miséria das massas populares - "estas são as condições objetivas do Brasil, capazes de levar o país à luta armada”. ${ }^{30}$ No mesmo sentido, em uma mensagem sobre a OLAS, através da Rádio Havana, o revolucionário afirmava:

(...) a luta revolucionária armada constitui a linha fundamental da Revolução na América Latina. Segundo palavras textuais da Declaração Geral, o problema, hoje, para a maioria de nossos países, é organizar, desenvolver e levar até o fim

\footnotetext{
${ }^{28}$ Jacob Gorender, op. cit., p. 104.

${ }^{29}$ Carta ao Comitê Central, in: Edgard Carone, O movimento Operário no Brasil (1964-1984), São Paulo, Difel, 1984, p. 51.

30 "Respostas ao questionário do Pensamento Crítico", in: Edgard Carone, op. cit., p. 44.
} 
a luta armada. O método eficaz para levar avante a luta armada revolucionária é a guerrilha. ${ }^{31}$

O próximo passo seria o de tentar adaptar às condições do Brasil as ideias cubanas. A primeira tentativa se deu quando Marighella ainda se encontrava em Cuba, no texto intitulado Algumas questões sobre as guerrilhas no Brasil, ${ }^{32}$ publicado no Jornal do Brasil, em setembro de 1968, mas escrito em Havana, em outubro de 1967, sob o impacto do assassinato de Che Guevara na Bolívia. O documento reveste-se de importância na medida em que pode ser tomado como a primeira elaboração feita por Marighella de uma teoria geral sobre a guerrilha no Brasil.

Em primeiro lugar, Marighella destaca que a guerrilha havia assumido, nos anos 1960, uma nova dimensão: a de papel estratégico decisivo na libertação dos povos. Isso porque, até então, as experiências das revoluções socialistas haviam sido caracterizadas pela transformação da guerra anti-imperialista mundial em guerra civil pela tomada do poder, apoiadas no triunfo da revolução de outubro na Rússia. A revolução cubana, por sua vez, trouxera ao marxismo-leninismo um novo conceito: "o da possibilidade de conquistar o poder através da guerra de guerrilhas, e expulsar o imperialismo quando não há guerra mundial e não se pode, portanto, transformá-la em guerra civil". ${ }^{33}$ Nesse sentido, a contribuição teórica e prática de Cuba ao marxismo teria elevado a guerrilha a um ponto inteiramente novo, "colocando-a na ordem do dia por toda parte, em especial na América Latina" 34

No caso brasileiro, caberia apontar as características fundamentais que a guerrilha poderia assumir. A estratégia central deveria ser a expulsão e o aniquilamento do imperialismo norte-americano e das forças militares brasileiras. Para isso, diante da ofensiva global do imperialismo, seria necessário também aos revolucionários o esforço para expandir a revolução por toda a América Latina e tornar efetiva a palavra de ordem de "criar dois, três, muitos Vietnãs". ${ }^{35}$

\footnotetext{
31 "Mensagem sobre a OLAS através da Rádio Havana" (Anexo Brasil Nunca Mais: 59).

32 "Algumas questões sobre as guerrilhas no Brasil", in: Escritos de Carlos Marighella, op. cit., p. $117-130$.

${ }^{33}$ Ibidem, p. 117.

${ }^{34}$ Ibidem, p. 118.

${ }^{35}$ Ibidem, p. 118-119.
} 
O primeiro cuidado da guerrilha no Brasil deveria ser o de evitar o "cerco estratégico do inimigo", o que significa dizer que ela deveria ser desencadeada fora da faixa atlântica do país, que, por motivos históricos, concentraria toda a força repressiva. Seria ainda necessário observar as três fases da luta guerrilheira que, mesmo não sendo estanques, deveriam ser consideradas em seu planejamento: 1. A do planejamento e preparação da guerrilha. 2. A do lançamento e sobrevivência da guerrilha. 3. A de seu crescimento e transformação em guerra de manobras. ${ }^{36}$

Certamente, é na fase de planejamento e preparação da guerrilha que percebemos mais claramente o quanto a permanência de Carlos Marighella em Cuba o tornou receptível às ideias foquistas, sobretudo àquelas que preconizam a possibilidade do desencadeamento da luta guerrilheira a partir da existência de um pequeno núcleo de militantes bem treinados e que, uma vez deflagrada, a guerrilha conseguiria aglutinar forças e apoio até a tomada do poder, seguindo a receita que teria sido utilizada em Cuba. Para Marighella, o requisito básico para a primeira fase da guerrilha é a "existência de um pequeno núcleo de combatentes, surgido em condições histórico-sociais determinadas". Este núcleo deve ser imune aos partidos da esquerda tradicional e conduzir a luta ideológica contra o "grupo de direita oposto à luta armada". Por fim, nesta fase, seria necessário o adestramento dos combatentes em tiro e marcha a pé, "algumas armas e munições", a exploração do terreno, noções de sobrevivência e orientação, e organização inicial do apoio logístico, o que incluiria a coleta de recursos. ${ }^{37}$

Em resumo, o revolucionário brasileiro assumia as principais teses propostas pelo foquismo: a não necessidade de um partido para guiar a guerrilha, o campo como cenário ideal para o seu desencadeamento e a crença de que um pequeno núcleo de guerrilheiros poderia dar início à luta, aglutinar forças e chegar ao poder. Em suas palavras: "partindo do marco zero, a guerrilha possibilita a organização da força do povo, a princípio sob forma de um pequeno núcleo de combatentes que se lança à luta, dentro de um plano estratégico e tático global". Em seguida,

(...) a guerrilha dá um salto para frente. E passa do tipo de organização de grupos guerrilheiros para o tipo de organização de um exército revolucionário. Mas um exército revolucionário não convencional, surgido da guerrilha, com base

\footnotetext{
${ }^{36}$ Ibidem, p. 122.

${ }^{37}$ Ibidem, p. 122-123.
} 
na aliança armada de operários e camponeses, aos quais se reunirão estudantes e outras forças da revolução brasileira. ${ }^{38}$

\section{O surgimento da ALNe o desencadeamento da guerrilha}

De volta ao Brasil, Marighella partiu imediatamente ao trabalho de organização de um grupo que pudesse colocar em prática as ideias sobre a luta armada. Nesse momento, houve pelo menos duas atitudes entre os militantes que já o acompanhavam na crise interna que tomava conta do PCB. De um lado, muitos se juntaram ao Agrupamento Comunista, criado por Marighella e pouco tempo depois transformado em ALN. ${ }^{39}$ Por outro lado, a adoção da guerrilha como único caminho de luta contra a ditadura militar afastou militantes que eram simpáticos ao marighellismo, mas que não concordavam com o caminho das armas.

Foi o caso, por exemplo, de Fernando Perrone. Procurado por Marighella no mesmo dia em que voltou de Cuba, ouviu claramente do líder da ALN que "a estratégia da revolução no Brasil é a guerrilha" e que não valia à pena tentar fazer o PCB mudar o seu rumo; o importante era "ganhar os comunistas, não o partido". ${ }^{40}$ Ainda segundo Perrone, outros militantes que apoiaram Marighella na luta interna não o acompanharam na proposta de luta armada. Nesse sentido, cita o caso de José Mariano de Souza, funcionário da Assembleia Legislativa de São Paulo, que teria dito: "apoiar o Marighella na luta interna, tudo bem. Mas abandonar o partido isso nunca". E o próprio Perrone afirma: "tínhamos uma profunda dificuldade de escolher entre Marighella e o partido. Eu também me sentia dividido e mantive essa ambiguidade, não por oportunismo, mas por falta de clareza, e também por minhas funções parlamentares". ${ }^{41}$

Provavelmente Marighella não estava muito preocupado com o número de militantes que o acompanharia no início da luta armada. Isso porque o tipo de organização que ele propunha se diferenciava de um partido político

\footnotetext{
${ }^{38}$ Ibidem, p. 128.

${ }^{39}$ Ver a esse respeito os depoimentos de ex-dirigentes do PCB, como Apolônio de Carvalho e Marco Antônio Coelho, que relatam a atração que as ideias de Marighella exerciam dentro do partido, sobretudo entre os jovens militantes (Apolônio de Carvalho, Vale a pena sonhar, Rio de Janeiro, Rocco, 1997 e Marco Antônio Coelho, Herança de um sonho. As memórias de um comunista, Rio de Janeiro, Record, 2000).

${ }^{40}$ Fernando Perrone, Relatos de guerras: Praga, São Paulo, Paris, São Paulo, Busca Vida, 1988, p. 76.

${ }^{41}$ Ibidem, p. 77.
} 
e, por suas características, não poderia ser uma agremiação de massas. Pelo menos é o que se pode perceber no documento Pronunciamento do Agrupamento Comunista de São Paulo, no qual acontece o rompimento público com o PCB e se anuncia a criação de uma organização revolucionária de novo tipo: "clandestina, pequena, bem estruturada, flexível, móvel. Uma organização de vanguarda para agir, para praticar a ação revolucionária constante e diária, e não para permanecer em discussões e reuniões". ${ }^{2}$

A linha política adotada pelo Agrupamento, segundo o documento acima, é a da Declaração Geral da OLAS e partia do pressuposto de que a guerrilha era a vanguarda revolucionária, o seu núcleo fundamental, constituindo-se no centro do trabalho dos comunistas e patriotas. Os princípios que regiam a nova organização eram três: "o primeiro é que o dever de todo revolucionário é fazer a revolução; o segundo é que não pedimos licença para praticar atos revolucionários e o terceiro é que só temos compromisso com a revolução". ${ }^{43}$

É importante salientar que o novo grupo preconizava que as principais tarefas políticas deveriam estar subordinadas à guerrilha e que, naquele momento, diziam respeito exatamente à sua preparação e criação do apoio logístico. Além disso, o comando geral da organização pertence à guerrilha, "onde quer que ela esteja". ${ }^{44}$ Por fim, no que concerne à estratégia geral a ser implementada, propunha que se deveria partir diretamente para a ação. $\mathrm{Na}$ célebre frase, que viraria uma marca da ALN, afirma o documento: "o conceito teórico pelo qual nos guiamos é o de que a ação faz a vanguarda". ${ }^{4}$

Para colocar em prática o seu projeto, a organização estruturou-se a partir de um modo mais militar do que político, refletindo uma crítica prática ao modelo dos partidos comunistas e o antiteoricismo, que caracterizaria tão fortemente a esquerda revolucionária brasileira nos anos 1960. No caso da ALN, ela era dividida entre o Grupo de Trabalho Estratégico (GTE), responsável pelo planejamento e implementação da guerrilha rural; o Grupo Tático Armado (GTA), voltado para as ações armadas; e o Grupo de Ação (GA), que deveria estar ligado ao trabalho de massa. Havia ainda os Grupos Independentes (GI's), setores de apoio, simpatizantes, sem uma ligação orgânica com

\footnotetext{
42 "Pronunciamento do Agrupamento comunista de São Paulo", in: Escritos de Carlos Marighella, op. cit., p. 133.

${ }^{43}$ Ibidem, p. 134.

${ }^{44}$ Ibidem, p. 136.

${ }^{45}$ Ibidem, p. 137.
} 
a organização. Enfim, acima desses setores, havia o Conjunto Regional e o Conjunto Nacional. ${ }^{46}$ É difícil falar em números de uma organização como a ALN, que desde o seu surgimento atuou na clandestinidade. Normalmente, afirma-se que foi a maior das organizações da esquerda armada. Por exemplo, no momento da saída do PCB, segundo Moisés Vinhas, teria deixado o partido, junto com Marighella e Câmara Ferreira, cerca de 10.000 militantes. Já na estimativa de Elio Gaspari, a ALN tinha, por volta de 1969, em torno de 300 militantes. $^{47}$

Com essa concepção e estrutura, a ALN se lançou no desencadeamento da guerrilha ainda em 1967, mas sem se identificar como organização revolucionária. A primeira ação se deu no interior de São Paulo, no município de Presidente Epitácio. No local, havia um conflito entre posseiros e o fazendeiro José da Conceição Gonçalves. Um militante da ALN, juntamente com outros camponeses, invadiu a sede da fazenda e matou o fazendeiro.

As primeiras ações guerrilheiras, entretanto, tinham a finalidade de angariar fundos para a implantação da almejada guerrilha rural e eram feitas de forma anônima. A ideia era se fortalecer e deixar a polícia pensar que se tratava de crimes realizados por bandidos. Nesse caminho, praticou dezenas de assaltos a bancos, a carros que transportavam dinheiro e mesmo a um trem pagador na estrada de ferro Santos-Jundiaí, do qual participou o próprio Marighella. O grupo fez ainda algumas expropriações de armas e explosivos nesse momento inicial.

No decorrer de 1968, os assaltos se intensificaram. Ao mesmo tempo em que praticavam assaltos, membros da ALN também se dedicavam à procura de áreas adequadas para a implantação de futuras bases de apoio para a guerrilha. A descoberta, por parte da polícia, da existência da organização guerrilheira aconteceu no final de 1968, quando um dos participantes de um assalto foi identificado e preso. Sob tortura, relatou aos policias a origem das atividades. ${ }^{48} \mathrm{~A}$ descoberta, entretanto, não fez diminuir a atuação da organização. Isso porque, de um lado, a polícia não estava preparada para lidar com esse tipo de ação; por outro lado, a ALN se fortaleceu ainda mais no primeiro semestre de 1969 , na medida em que retornavam os militantes que faziam

\footnotetext{
${ }^{46}$ Sobre a estruturação da ALN, ver Marcelo Ridenti, op. cit., p. 41.

${ }^{47}$ Moisés Vinhas, op. cit., p. 242. Elio Gaspari, A ditadura envergonhada, São Paulo, Companhia das Letras, 2002, p. 142.

${ }^{48}$ A respeito das ações da ALN, ver Jacob Gorender, op. cit., p. 108-109.
} 
treinamento guerrilheiro em Cuba. ${ }^{49}$ Ainda em 1969, a ALN participou, em conjunto com o MR-8, do sequestro do embaixador americano no Brasil.

\section{Otreinamento guerrilheiro e a ligação orgânica com a revolução cubana}

Durante a maior parte do tempo em que existiu, aproximadamente de 1968 a 1974, a ALN enviou membros para fazerem treinamento militar em Cuba. Entre todas as organizações que fizeram o treinamento, a ALN foi a que mais militantes enviou. Entre 1967 e 1970, foram enviadas quatro turmas, totalizando cerca de 92 deles. O treinamento era basicamente militar, com instruções de tiro, fórmulas explosivas, montagem e desmontagem de armas. Havia ainda, ao final do curso, um exercício de sobrevivência com simulação de combate com exército cubano. ${ }^{50}$

Para Marighella, a ideia era de que o treinamento se restringisse aos aspectos militares, não devendo significar uma interferência cubana nas decisões e orientações da ALN. Havia, certamente, uma política de apoio à revolução cubana e mesmo certa inserção dentro da ideia de uma revolução continental, mas sem interferência de um país sobre outro. Isso não significava, como mostra o livro de Denise Rollemberg, que não houvesse setores da ALN que achassem natural uma liderança cubana ou que os próprios cubanos não tentassem usar a sua influência e interferir nos rumos da organização. Essa tentativa podia se dar, por exemplo, escolhendo-se, entre os militantes que estavam em treinamento, o "comandante" do grupo ou mesmo privilegiando informações e contatos em Cuba para aqueles que fossem mais permeáveis à sua influência..$^{51}$

De qualquer forma, o importante é que não há indícios de que a ALN tenha sido orientada pelos cubanos na elaboração e aplicação de sua linha política. A influência de Cuba sobre a ALN não está exatamente em sua re-

\footnotetext{
${ }^{49}$ Ibidem.

${ }^{50} \mathrm{E}$ importante frisar que as turmas de militantes da ALN incorporavam guerrilheiros de outras organizações. De qualquer forma, o importante a sublinhar é que a ALN foi o grupo que mais militantes enviou para o treinamento. Ver a esse respeito Denise Rollemberg, $O$ apoio de Cuba à luta armada no Brasil: o treinamento guerrilheiro, Rio de Janeiro, Mauad, 2001, p. 40-41.

${ }^{51}$ Sobre as avaliações de Marighella a respeito do significado do treinamento guerrilheiro, das relações da ALN com os cubanos e do papel de Cuba na estratégia revolucionária do continente em geral, e do Brasil em particular, ver: ibidem, p. 47-49. Ver ainda Denise Rollemberg, "A ALN e Cuba: apoio e conflito", Cadernos AEL, v. 8, n. 14/15, Campinas, 2001, p. 205-251.
} 
lação orgânica, devendo ser buscada em outra dimensão. Como vimos acima, ela está na inspiração que suscitou a Carlos Marighella na elaboração de sua estratégia de luta contra a ditadura militar, a qual aceita o núcleo das ideias foquistas, mas que apresenta especificidades relacionadas à realidade política e geográfica brasileira.

\section{"A guerrilha não é um foco"}

Não são apenas as interpretações recentes que apontam a ALN como uma organização de matriz foquista. Durante os anos 1960 e 1970, foi mais de uma vez criticada por outros grupos por seguir orientações cubanas, a começar pela própria direção do PCB que, nos documentos de seu VI Congresso, combateu fortemente os agrupamentos que exigiam uma opção pela luta armada, entre os quais se encontrava Marighella. Segundo o partido, tais militantes estariam tentando, de forma equivocada, aplicar no Brasil ideias oriundas da experiência cubana.

Certamente, pesou, nas interpretações passadas e recentes sobre a adesão de ALN ao foquismo, a presença de Carlos Marighella na OLAS; a sua relação privilegiada com Fidel Castro; o grande número de militantes enviados para fazer o treinamento em Cuba e a adoção das resoluções da OLAS como bandeira política. De qualquer forma, como venho defendendo até aqui, a ALN não pode ser caracterizada como uma organização tipicamente foquista, pelo menos nos termos defendidos por Che Guevara e Régis Debray. Na verdade, a ALN de Marighella pode ser tomada como um dos exemplos mais representativos do tipo de influência exercida pela revolução cubana sobre a esquerda revolucionária brasileira; ou seja, uma organização que, inspirada por Cuba e partindo das ideias centrais do foquismo, tenta adaptar esse ideário à realidade brasileira e à luta contra a ditadura militar, chegando a um tipo de proposta que contemplava tradições variadas, inclusive algumas que vinham do PCB, do qual grande parte dos militantes da ALN tinha origem.

A respeito da adaptação feita por Marighella das ideias centrais do foquismo, além da óbvia necessidade colocada pela realidade geográfica brasileira, tão diferente da cubana, um aspecto não pode ser desprezado no entendimento da questão. Como já indicou Muniz Ferreira, o fracasso de Che Guevara e Régis Debray na Bolívia, bem como outros eventos de menor monta, na tentativa de implementação do foco, teriam abalado a crença na validade da teoria foquista, levando à necessidade de ajustes "programáticos ao foquismo 
original". ${ }^{52}$ Assim, Marighella teria acrescentado à teoria guevarista-debraysta elementos da estratégia revolucionária chinesa e argelina. ${ }^{53}$ Ainda no caminho do entendimento das mudanças implementadas na teoria do foco, Jacob Gorender vê influências de Georges Sorel e Frantz Fanon no pensamento do líder da ALN, além das lições tiradas da malograda guerrilha do Caparão. ${ }^{54}$

O próprio Marighella se manifestou a fim de esclarecer que a sua organização não era foquista. Em abril de 1968, no primeiro número do jornal $O$ guerrilheiro, a ALN afirmava de modo a não deixar dúvidas: "a guerrilha nãoé um foco". E continuava: "pensamos sobre a guerrilha o mesmo que a conferência da OLAS (...) no ponto 10 de sua Declaração Geral, que a apresenta como embrião dos exércitos de libertação e como método mais eficaz para iniciar e desenvolver a luta revolucionária". ${ }^{55}$ No caso do Brasil, dada a sua dimensão continental, Marighella introduz a ideia de guerrilha como guerra de movimento no lugar de foco ${ }^{56}$ e falaria ainda de guerrilha em forma de marcha e das colunas guerrilheiras móveis. ${ }^{57}$ Como se percebe pela nomenclatura, a ideia do líder da ALN era a de que no Brasil a guerrilha deveria ser móvel, atacar em locais variados e não se fixar em um território, diferentemente da revolução cubana, em que, a partir da Sierra Maestra, os guerrilheiros expandiram suas forças até a tomada do poder.

Outra mudança significativa introduzida por Marighella na teoria foquista é a valorização da guerrilha urbana como luta política, o que não se encontra nas obras de Guevara e Debray. É possível pensar que a incorporação de tal elemento está diretamente ligada à própria realidade brasileira. Ou seja, ainda que houvesse a ideia de que a guerrilha se daria no campo, os seus principais militantes, recursos e mesmo a efervescência política se encontravam nas cidades. Assim, se nos primeiros documentos sobre a questão a guerrilha urbana aparece como uma fase necessária antes de se partir para o campo,

\footnotetext{
${ }^{52}$ Muniz Ferreira, op. cit., p. 247.

${ }^{53}$ Ibidem, p. 248.

${ }^{54}$ Jacob Gorender, op. cit., p. 105.

${ }^{55}$ O guerrilheiro, n. 1, abril de 1968 (Anexo BNM: 4274).

56 “O papel da ação revolucionária na organização", op. cit., p. 215.

57 “Alocução sobre a guerrilha rural”, in: Edgard Carone, op. cit., p. 58.
} 
pouco a pouco ela vai sendo valorizada até ocupar um espaço estratégico no projeto da ALN. ${ }^{58}$

Da mesma forma, e fruto das difíceis condições de luta contra a ditadura, que em um movimento crescente passa a utilizar a tortura como política de estado, a organização adotou a ideia do uso do terrorismo de esquerd $a^{59}$ como forma de se fazer propaganda política e mesmo de eliminação de pessoas ligadas ao regime militar e ao imperialismo norte-americano. O exemplo mais representativo, tanto da importância da guerrilha urbana, como do uso do terrorismo, está na publicação, assinada por Marighella, do conhecido Pequeno manual do guerrilheiro urbano, de 1969, que veio inclusive a ser traduzido em várias línguas e usado por grupos radicais na Europa ocidental nos anos 1970.

Ainda sobre as diferenças do programa da ALN em relação ao foquismo, vale lembrar aqueles elementos que a organização herdou do PCB, como a ideia da revolução feita em duas etapas. Ou seja, a primeira delas seria "burguesa" ou de "libertação nacional", liderada a partir da união de setores progressistas da sociedade, que teriam em comum o interesse de desenvolver as forças produtivas e, assim, acabar com os resquícios feudais no campo e com a presença do imperialismo norte-americano. Somente depois de cumprida essa etapa, iria se passar para a revolução socialista. É certo que a ALN não seguia exatamente a ideia clássica da revolução por etapas, havendo em seu discurso nuanças que apontavam para um maior radicalismo. ${ }^{60}$ Entretanto, interessa-nos ressaltar que a ALN não defendia uma revolução imediatamente socialista, o que a distancia do pensamento de Che Guevara e Régis Debray. ${ }^{61}$

Em que pesem as mudanças implementadas pela ALN na teoria do foco no que se refere à adaptação à realidade brasileira, no final das contas, a organização, como vimos no decorrer deste artigo, acabou por manter em seu programa o núcleo do foquismo. Ou seja, partia do pressuposto de que um pequeno grupo que inicia a luta armada incorpora forças até chegar ao poder e aceitava a guerrilha como vanguarda política da revolução, subordinando todos os outros elementos da luta contra a ditadura a este postulado. Assim,

\footnotetext{
${ }^{58}$ Ver a esse respeito o documento "O papel da ação revolucionária na organização", op. cit., p. 215 e "Quem samba fica, quem não samba vai embora", in: Cristina Nova e Jorge Nóvoa (orgs.), op. cit., p. 548.

${ }^{59}$ Jacob Gorender, op. cit., p. 106.

${ }^{60}$ Para Muniz Ferreira, as circunstâncias da luta guerrilheira e o pouco apego às discussões teóricas acabaram por levar a ALN a um certo "improviso" no terreno da teoria, daí decorrendo a "ausência de precisão estratégica" de sua parte (Muniz Ferreira, op. cit., p. 251).

${ }^{61}$ Algumas diferenças entre o programa da ALN e o foquismo podem ser vistas em Marco Aurélio Garcia, “ALN - A ação faz a vanguarda”, Em tempo, São Paulo, 1979.
} 
pode-se afirmar que as diferenças em relação ao foquismo são secundárias, não passando de aspectos táticos necessários diante da realidade geográfica e política brasileira, mas que não abandonava as ideias centrais de Régis Debray e Che Guevara. Este último, assim como Marighella, foi morto por forças repressivas; um, na selva boliviana, outro, na cidade de São Paulo. Os dois imbuídos essencialmente do mesmo projeto político.

Após a morte de Carlos Marighella, em novembro de 1969, assumiu o comando da organização Joaquim Câmara Ferreira, histórico militante comunista que esteve ao lado de Marighella desde a época da crise dentro do PCB. O novo dirigente, também conhecido como Toledo, procurou fazer duas mudanças na ALN. A primeira foi uma tentativa de criar uma direção mais centralizada para a organização. A segunda foi procurar imprimir um ritmo forte de ações militares urbanas, no intuito de reforçar a presença da ALN no combate à ditadura.

A tentativa de Toledo de manter o ritmo de ações da ALN não surtiu o efeito desejado. Vale lembrar que essa nova fase coincide com o fortalecimento do aparato repressivo e com o uso da tortura como método investigativo, o que levou ao esfacelamento das organizações revolucionárias. O próprio Joaquim Câmara Ferreira sentiu na pele os horrores dos porões da ditadura. Preso em outubro de 1970, morreu torturado.

Da morte de Toledo até o desaparecimento da ALN, por volta de 1974, o grupo passou por um processo de isolamento e diminuição de seus efetivos. Continuou com as ações expropriatórias, designação política dada pelos revolucionários aos assaltos a bancos, mas que, nesse momento, significava pura sobrevivência física. Ao mesmo tempo, em seus momentos finais, sofreu duas cisões, que deram origem ao Movimento de Libertação Popular (MOLIPO) e à Tendência Leninista (TL). O MOLIPO surgiu a partir de uma turma de militantes que fazia treinamento em Cuba. Em desacordo com a linha da ALN, o grupo rompeu com a organização ainda fora do país. Ao voltar para o Brasil, seus cerca de trinta militantes foram quase todos mortos pela polícia. A TL, por sua vez, foi uma cisão circunscrita aos militantes que se encontravam no exílio e propunham a reorganização do grupo em forma de partido político. Teve pouca repercussão no Brasil e dissolveu-se em 1974. ${ }^{62}$ Ainda naquele ano, a ALN, nas palavras de Marco Aurélio Garcia, "desapareceu como havia surgido: sem formalidades", e a maior parte de seus remanescentes voltou ao PCB. ${ }^{63}$

${ }^{62}$ Jacob Gorender, op. cit., p. 228-229.

${ }^{63}$ Marco Aurélio Garcia, "ALN - A ação faz a vanguarda”, op. cit. 